\title{
DISPROOF OF INCONVENIENT NEGATIVE COURT PRACTICE FOR SELF-PROTECTION IN ECONOMIC ACTIVITY
}

\author{
Leonid Belkin', Julia Iurynets ${ }^{2}$, Mark Belkin ${ }^{3}$, *Yuriy Pyvovar ${ }^{4}$ \\ ${ }^{1}$ PhD. Self-employed person, Kyiv, Ukraine.E-mail belkinleonid@ukr.net \\ ${ }^{2}$ Assoc. Prof. Dr. National Aviation University, Kyiv, Ukraine.E-mail iurynetsjulia@ukr.net \\ ${ }^{3}$ PhD. Maurice Group Law Company, Kyiv, Ukraine.E-mail advokat@etalon.co.ua \\ ${ }^{4}$ Assoc. Prof. PhD. National Aviation University, Kosmonavta Komarova str. 1, 03058 Kyiv, \\ Ukraine.Phone+380673334886. E-mail pyvovaryi@gmail.com
}

Received 1012 2018; accepted 05032019

In an environment where governments require more and more money to fulfill social obligations, and the business opportunity to pay taxes is decreasing, there are dangers of pressure from the authorities on business entities to increase payments. Often, without having enough evidence of the bad faith of the taxpayer, the authorities create artificial judicial prejudices. This requires the development of protective preventive mechanisms in economic activity, which should be directed to the disproof of inconvenient negative court practice. The purpose of this work is to develop new protective and preventive advice in economic activity, which will be based on the disproof of inconvenient negative court practice. Research Methodology: systematization of approaches to the consideration of tax disputes in courts, ways and methods of effective use of disproof of inconvenient negative court practice for the implementation of protective preventive mechanisms in economic activity. Results of the research - recommendations have been developed that allows for ensuring effective disproof of inconvenient negative court practice for the introduction of protective and preventive mechanisms in economic activity.

Keywords: administrative legal proceedings, economic legal proceedings, judicial practice, protective preventive mechanisms, rights of entrepreneurs, selfdefense.

JEL Codes: J52, K22, K41, L26.

\section{Introduction}

Relevance of the topic. Although the article is written mainly on the materials of the judicial practice of Ukraine, it is relevant for many developed countries the European Union (EU) countries and Russia, where the main taxes are value added tax (VAT) and income tax. Thus, in par. 20 of the decision of European Court of Human Rights (ECHR) in the case of "BULVES AD v. BULGARIA" stated: "The VAT Act

Copyright (C) 2019 The Authors. Published by Vytautas Magnus University, Lithuanian Institute of Agrarian Economics. This is an open access article distributed under the terms of the Creative Commons Attribution NonCommercial 4.0 (CC BY-NC 4.0) license, which permits unrestricted use, distribution, and reproduction in any medium, provided the original author and source are credited. The material cannot be used for commercial purposes. 
came into force on 1 January 1999. Although at the time Bulgaria was not a member of the EU, domestic VAT legislation in many respects followed the provisions of Council Directive 77/388/EEC of 17 May 1977 on the harmonization of the laws of the Member States relating to turnover taxes, known as the Sixth VAT Directive, which at the time was the principal basis for the system of value-added tax in the EU". To the extent that this conformity applies to Bulgaria, this also applies to Ukraine.

At the same time, the calculation of these taxes (VAT and income tax) is highly dependent on the tax modification of deal. For example, in par. 32 of the decision of European Court of Human Rights (ECHR) in the case of "BULVES AD v. BULGARIA" stated: "By contrast, where it is ascertained, having regard to objective factors, that the supply is to a taxable person who knew or should have known that, by his purchase, he was participating in a transaction connected with fraudulent evasion of value added tax, it is for the national court to refuse that taxable person entitlement to the right to deduct".

Recently, in the EU, the feeling of relatively significant VAT shortfalls is growing. For example, according to the Report "VAT Gap", EU countries lost an estimated total of $€ 152$ billion in Value-Added Tax (VAT) revenues in 2015, according to a new study by the European Commission. This raises reasonable concerns about increasing pressure on entrepreneurs to change the tax assessment of the deal.

So, the researcher Sergeev (2017) notes that to counteract an unfounded application of deducting the input VAT by unscrupulous taxpayers, the tax authorities intend to limit the receipt of tax benefits when performing taxable VAT operations. This restriction is carried out by collecting arrears not from the seller due to the widespread cases of his lack of enough assets, as well as information about controlling persons, but from the buyer of goods, works or services, receiving the right to reduce his tax base. However, a taxpayer claiming a tax deduction on goods or services purchased may not always be aware of his counterparty not paying taxes, that is, responsibility for the actions of an unscrupulous seller may be imputed to the taxpayer by tax authorities regardless of his fault. The author notes that the peculiarity of the German law is the presumption about the knowledge or necessity of the taxpayer's knowledge of non-payment of tax by his counterparty when the transaction price is below the market level or deviating from the prices of the same taxpayer for the goods sold by him.

Ukrainian researcher Logwin (2017) reports that the possibility should not be ruled out that the reality of a business transaction for which a tax invoice was made and registered may later be questioned. This may occur in the case of obtaining information about the existence of a court sentence against the counterparty supplier, who was found guilty of committing a crime under Art. 205 of the Criminal Code of Ukraine ("Fictitious Entrepreneurship") or the closure of such criminal proceedings on non-rehabilitating grounds. Numerous examples of the use of court sentences in relation to some individuals for additional tax accrual to others (even not always to counterparties) are given in the authors' articles (2018). 
Ukrainian lawyer Golovan (2003) emphasized that protecting the rights and legitimate interests of business entities includes activating the legal actions of the entity itself in the fight against violations of the law and the most complete use of the legislative framework to protect their rights and interests. Consequently, the issue of the protection of business entities in economic and managerial relations is relevant

A reliable solution to the issues of the safety of business entities is aggravated by the propensity of administrative courts, which resolve legal disputes with the subjects of power, with the slightest opportunity to make decisions in favor of the authorities. And this «tradition» is also inherent not only in Ukraine. Thus, in the case of "Janezevik v. Sweden" and "Västberga Taxi Aktiebolag" and "Vulic v. Sweden", the ECHR noted that "in such cases, when dealing with the question of the proper balance of interests, the Court tends to the side of the state". Consequently, preventive (preceding the practical occurrence of dangers) the use of security measures is relevant to any democratic system. These methods were developed in the monograph Belkin (2014), articles Belkin L. (2018), Belkin M. (2012) and in a joint article of the authors (Belkin, L., Belkin, M., Iurinets, 2018; Bazov, Pyvovar, 2017). At the same time, the possibility of using private law methods for the next defense of rights in public relations is put into the forefront. This article summarizes these developments.

The scientific problem that is solved in this work is that the concept of "selfdefense of civil rights" is known, mainly in civil law, for example, the dissertation of the Russian Scientist Goncharov (2006). Article 19 of the Civil Code of Ukraine states that a person has the right to self-defense of his civil rights and the rights of another person against violations and unlawful encroachments. Self-defense is the use by a person of countermeasures that are not prohibited by law and do not contradict the moral foundations of society.

The object of the research are methods and ways of preventive business protection. The aim of this paper - to develop new protective preventive advice in economic activity, which will be based on disproof of inconvenient negative court practice. Tasks of the study: 1) determine the strategies, methods and techniques for disproof of inconvenient negative court practice; 2) prepare recommendations for disproof of inconvenient negative court practice; 3 ) to prepare recommendations on the disproof of inconvenient negative court practice.

\section{Methods}

Research methodology: systematization of approaches to the consideration of tax disputes in courts, of ways and methods of effective disproof of inconvenient negative court practice the implementation of protective preventive mechanisms in economic activity.

When doing work studied and summarized: Decision of European Court of Human Rights (ECHR) in the case of "BULVES AD v. BULGARIA"; Judgment of 12 January 2006 of the Court of Justice of the European Union in joined cases C-354/03, C355/03 and C-484/03, Optigen Ltd (C-354/03), Fulcrum Electronics Ltd (C-355/03) 
and Bond House Systems Ltd (C-484/03) v. Commissioners of Customs \& Excise: reference for a preliminary ruling from the High Court of Justice (England \& Wales), Chancery Division - United Kingdom, European Court Reports (ECR) 2006, page I00483, the CJEC; Judgment of 6 July 2006 in joined Cases C-439/04 and C-440/04, Axel Kittel v Belgian State (C-439/04) and Belgian State v. Recolta Recycling SPRL (C-440/04) (ECR 2006, page I-06161); 3000 court decisions of Ukrainian courts, the authors' own court practice.

\section{Results and Discussions}

As indicated above, in economic and administrative practice there are cases when government agencies, first, tax (fiscal) services, attain Inconvenient Negative Court Practice in courts, and then use them for questionable additional tax accrual. The grounds for the cancellation of dubious court decisions that the government wants to use as a basis for additional tax accrual can be such situations.

1) Violation of rules of jurisdiction. So, after the $1^{\text {st }}$ of September 2005 cases on the lawsuit of the subjects of power authorities should be considered not in the order of civil, but in the procedure of administrative proceedings. Consideration in accordance with the procedure of civil proceedings is a violation, which entails the cancellation of a court decision closing the proceedings. For example, the decision of the Desniansky District Court of Kyiv dated the $15^{\text {th }}$ of June 2006, met the claim of the STA in Kyiv on the invalidation of the statutes of Ltd "M" and of the Open Joint Stock Company "M", which subsequently served as the basis for several tax deductions. According to the results of consideration of the appeal filed, the Kyiv Court of Appeal admitted that the bodies of the State Tax Service were granted the right to apply, in cases provided for by law, to the administrative court with a statement of claim on the cancellation of the state registration of the subject of entrepreneurial activity. Considering the fact that the dispute arose after the appeal of the subject of authority the STA in Kyiv, the panel of judges found that such a dispute is not subject to review in civil proceeding, and therefore the court decision was quashed with the closure of the proceedings. By a decision of the Supreme Court of Ukraine dated the $12^{\text {th }}$ of Mart 2008 No 6-2931sk08, the decision was refused on the opening of the cassation proceedings. It should also be noted that the Court of Appeal of Donetsk Region in its ruling the $31^{\text {st }}$ of October 2006 in case No 22-9724, the Court of Appeal of Zaporizhzhia Oblast, in its ruling the $30^{\text {th }}$ of November 2006, in the case No 22$6690 / 2006$, and the like, came to similar conclusions. True, it should be noted that in this case, tax authorities are not deprived of the right to apply to the court again - now to the administrative.

2) Wrong choice of subject of power of a method of action. Tax authorities have no right to sue for the invalidation of constituent documents and certificates of the VAT payer, as well as all issued primary documents. The legal position on the absence of the right of the tax authorities to appeal to a court with a claim for the invalidation of constituent documents of his time was set forth in the decision of the SEC the $11^{\text {th }}$ of July 2007 in the case No 27/295-05. The SEC draws attention to the need to assess the 
legal grounds for seeking a tax authority to court with the requirement to invalidate constituent documents, which is not provided by law. The Dnipropetrovsk Administrative Court of Appeal came to a similar conclusion (the ruling the $21^{\text {st }}$ of November 2007 in the case No 22-1256/07). The court recognized that the law does not provide for the right of tax authorities to appeal to the court with the requirements for the invalidation of the constituent documents of the enterprise (statute, certificate of state registration, certificate of inclusion in the state register), invalidation of registration of the VAT payer, cancellation of the certificate of the VAT payer, invalidation all accounting documents and other financial and economic documents from the moment of their drawing up and registration, therefore the court of first instance has accepted the legitimate and substantiated decision about refusal to satisfy such Outside requirements. It should also be considered that the current legislation does not provide for such a method of judicial protection, such as the invalidation of constituent documents and certificates of the VAT payer, as well as all primary documents issued by a legal entity. And since the termination of a legal entity even after a court decision comes only after the liquidation procedure has been completed and the exclusion of this person from the state register, it is impossible to automatically recognize all the activities of this legal entity as unlawful.

3) Adoption by courts of inadequate evidence. Decisions of courts on the invalidation of constituent documents and certificates of the VAT payer, as well as of all legal documents issued by a legal entity, are based, as a rule, on explanations of the founders. These explanations indicate that the founders did not intend to engage in entrepreneurial activity, that they signed the constituent documents for remuneration, by arrangement with other persons, had no relation to the formation of the authorized capital, etc. Such testimonies give justices a reason to consider the statute (foundation document of the enterprise) as a contract and apply to it articles 203 and 215 of the CC on the invalidation of contracts. But for the same administrative court, only a court verdict in a criminal case or a court order in an administrative offense, and not materials from investigations or other inspections that are not brought to trial, can be probative. Taking this into account, the Odessa Regional Court of Appeal, in the aforementioned resolution dated the $15^{\text {th }}$ of November 2006, in the case No 22a-1449/2006, indicated that the plaintiff had not provided evidence that the founder had entered into an agreement on the proposal of his casual acquaintances, whose names and whereabouts were unknown, without the intention to engage in financial, business and entrepreneurial activity, and in order to obtain money due to a difficult financial situation. And in the decision of the Kharkiv Administrative Court of Appeal of the $17^{\text {th }}$ of May 2007, in the case No 2-a-4/07, it is indicated that the judicial board does not take into account the information given in the testimony of a person and filed in the court with the plaintiff in the case - the tax authority, since these testimony were given by a person in the division of the plaintiff - in the tax police. In addition, it was noted that the fact of fictitious business can be established solely in the criminal justice system, not civil or economic. Thus, only the acknowledgement of individuals, 
including founders, cannot be exhaustive evidence of the illegality of the registration of an enterprise.

It should also be borne in mind that recently, especially after the adoption of the Criminal Procedural Code of Ukraine in 2012 and the incorporation of the provisions on recognition of guilty into it, various fiscal (tax police) and investigative bodies conduct the aforementioned "confessions" of fictitious business through sentences of criminal courts on the basis of "agreements" on the recognition of guilt. Such "sentences" represent a significant risk for counterparty enterprises, since the problems of challenging such "sentences", due to the relative novelty of the problem, have not yet been resolved (Trut, 2016). At the same time, the Supreme Court of Ukraine explained the possibility of such appeals by interested parties under certain conditions. It is no coincidence that the issue of the introduction of plea-bargaining agreements in criminal proceedings is debatable in Europe (Ervo, 2014; Gácsi, 2018).

\section{Conclusions}

1. The concept of civil rights self-defense in civil law relations should be extended to public law relationships - when the actions of the authorities - real or perceived - pose threats to the rights of business entities. The authors systematically investigate the situation in this area. Specific examples confirm cases of such negative judicial practice when it is created in civil or administrative or criminal proceedings. Determined by the strategies, methods and techniques for disproof of inconvenient negative court practice, prepared by the recommendations for disproof of inconvenient negative court practice. The cases of Violation of rules of jurisdiction; Wrong choice; Adoption by courts of inadequate evidence, approaches to appealing such court decisions were formulated, considering the need in some cases of restoring the time limits for appeal. Attention is drawn to the danger of sentences adopted based on agreements on conviction.

2. In this way, the scientific substantiation and recommendations for new areas of self-defense of economic entities in economic-managerial relations, which correspond to the current realities of increasing the pressure of state bodies on subjects of management, are formulated. Prospects for further exploration in this direction are a synthesis of new, emerging mechanisms of protection, as well as a synthesis of modern protection experience.

\section{Acknowledgements}

This article was supported in parts by Department of Constitutional and Administrative Law research work is state budget theme "Public-legal mechanism of guaranteeing Ukraine's national interests” No. 55/13.01.02.

\section{References}

Belkin, L. M. (2014). Ensuring legality in the activity of executive authorities: administrative and legal measure. - Uzhgorod: FOP Breza. 550 p.

Belkin, L. (2018). Administrative Court: the name is new, and the approaches to the judiciary 
are old. Stock world. - 31.10.2018. -https://www.stockworld.com.ua/ru/column/kasatsiiniiadministrativnii-sud-nazva-nova-a-pidkhodi-do-sudivnitstva-stari [10 02 2019].

Belkin, L., Belkin, M., Iurinets, Yu. (2018). Establishment of tax liability in administrative proceedings: the role of sentence under the plea agreement // Court appeal. No 4: 26-38. http://idpnan.org.ua/files/2019/sudova-apelyatsiya-_-4-_53_-_2018_.pdf [10 02 2019].

Belkin, M.L. (2012). Simplification of judicial preludes as a means of protecting the rights of taxpayers in administrative proceedings // Administrative law and process. No. 1: 96-105.

Gácsi, Anett Erzsébet. (2018). The "Plea Bargaining" in Hungary // Legal Bulletin. Air and Space Law. No 3 (48): 166-175.

Goncharov, E.I. (2006). Self-defense of civil rights and freedoms of a person and citizen (constitutional and legal aspect). Thesis of the Ph.D dissertation. Rostov n/D. $180 \mathrm{p}$.

Decision of European Court of Human Rights (ECHR) in the Case of ""BULVES" AD v. BULGARIA". - http://docs.pravo.ru/document/view/19676037/ [10 02 2019].

Laura, Ervo. (2014). Plea bargaining as an example of the recent changes in the Finnish criminal procedural paradigm // Baltic Journal of Law \& Politics. Vol. 7, No. 1: 97-112.

Logvin, A .V. (2017). Registered tax invoice - the basis and indisputable right for the formation of a tax credit // Visnyk Mariupolskoho derzhavnoho universytetu. Seriia : Pravo. Vyp. 14: 107-114.

Nepryakhina, N. (2015). The SFS continues to tighten the nuts of the business. RBK-Ukraine. 21.09.2015. - https://daily.rbc.ua/rus/show/gfs-prodolzhaet-zakruchivat-biznesu-nalogovye1442863889.html [10 02 2019].

Pyvovar, Y., Bazov, O. (2017). European court of human rights as the guarantor of legal protection of a human in the field of aviation activities of Ukraine // Proceedings of the National Aviation University. No 3(72): 120-126. DOI: 10.18372/2306-1472.72.11995 [10 02 2019].

Sergeyev, S.V. (2017). Concept of due care in Russian and German law // Matters of Russian and International Law. Vol. 7. Is. 2A: 111-122. - http://publishing-vak.ru/file/archive-law-20172/11-sergeev.pdf [10 02 2019].

European Commission. (2017). VAT Gap: EU countries lose $€ 152$ billion in 2015, showing urgent need for VAT reform. - http://europa.eu/rapid/press-release_IP-17-3441_en.htm [10 02 2019].

\title{
TEISMO SPRENDIMO PREJUDICINÉS GALIOS PRINCIPO TAIKYMAS KAIP SAVIGYNOS PRIEMONE் VERSLININKAMS GINANT SAVO TEISES SANTYKIUOSE SU VALDŽIOS INSTITUCIJOMIS
}

\author{
Leonid Belkin ${ }^{1}$, Julia Iurynets ${ }^{2}$, Mark Belkin $^{3}$, $*$ Yuriy Pyvovar ${ }^{4}$ \\ ${ }^{1}$ Dr., Kijevas, Ukraina, ${ }^{2,4}$ Nacionalinis Aviacijos universitetas, Kijevas, Ukraina, ${ }^{3}$ Maurice Grupes \\ teisès įmone, Kijevas, Ukraina
}

Gauta 201812 10; priimta 20190305

\section{Santrauka}

Straipsnyje plètojami ekonominėms veikloms skirti prevenciniai apsaugos mechanizmai, kurių tikslas - užtikrinti verslo subjektų teisių apsaugą santykiuose su valdžios institucijomis ir užkirsti kelią šių teisių pažeidimui. Atlikus ši mokslinį darbą, prie ekonominèje ir administracinèje praktikoje žinomų prevencinès apsaugos metodų, skirtų verslo subjektams, pasiūlyti nauji veiksmingi metodai, grindžiami tikslingu teismo sprendimo prejudicinès galios (reikalavimo apribojimo, angl. „collateral estoppel“) principo taikymu. Toliau plètojamos teorinès nuostatos dèl veiksmingu savigynos mechanizmų ekonominiuose ir valdymo santykiuose, pagrịstas platesnio teisinès veiklos 
galimybių panaudojimo ekonomikoje būtinumas, naujos veiksmingos teisinès veiklos taikant ịrankius ir metodus, skirtus ginti verslo subjektų teises ir interesus, sprendžiant teisinius ginčus, galimybès.

Raktiniai žodžiai: teisinis administracinis procesas, teismo sprendimo prejudicine galia, ekonominio teismo procesas, verslininku teisès, laikinoji apsauga, savigyna.

JEL kodai: J52, K22, K41, L26. 